\title{
PENDEKATAN LINGUISTIK DALAM PENGKAJIAN SUMBER HUKUM ISLAM
}

\author{
Nurlaila \\ Program Studi Raudatul Athfal STAIN Batusangkar \\ J1. Jenderal Sudirman No. 137, Lima Kaum Batusangkar \\ e-mail: nurlaila_zn@yahoo.co.id
}

\begin{abstract}
Approaches in Islamic studies should be appropriate with the object under studies. Linguistic approach is one of the approaches in Islamic studies whose object is scripture (manuscripts or texts). Therefore, as the main source of Islamic laws, al-Quran should use linguistics in one of its approaches. Linguistic approach which is used emphasizes upon two categories, namely linguistic and concept analyses as well.
\end{abstract}

Kata kunci: pendekatan, linguistik, al-qur'an, hermeneutik.

\section{PENDAHULUAN}

$\mathcal{P}_{\text {ilmu pengetahuan, termasuk di }}^{\text {erkembangan teknologi dan }}$ dalamnya perkembangan ilmu-ilmu sosial kemanusiaan yang begitu pesat secara relatif memperpendek jarak perbedaan antar budaya, antar satu wilayah dengan wilayah yang lain. Hal demikian, pada gilirannya juga mempunyai pengaruh yang cukup besar terhadap fenomena agama. Agama untuk era sekarang tidak lagi dapat didekati dan dipahami hanya lewat pendekatan teologis-normatif semata-mata (Abdullah, 1996: 9).

Dalam studi keagamaan kontemporer, telah terjadi revolusi pendekatan dan metode pemahaman keagamaan, dari pemahaman keagamaan yang semula hanya terbatas pada idealita menuju ke arah historisitas, dari yang hanya terbatas pada doktrin ke arah entitas sosiologi, dari diskursus esensi ke arah eksistensi (Mu'ammar dkk, 2012: 103). Metode studi agama yang digunakan dalam mengkaji agama, sangat bergantung objeknya, sebab objeklah yang menentukan metode, bukan sebaliknya (Suprayogo, 2001: 21). Dengan demikian, perkembangan pendekatan dalam studi agama menunjukkan semakin beragamnya objek yang dikaji.

$$
\text { Multiapproach (multi }
$$

pendekatan), multidisipliner, serta multiperspektif dalam studi Islam menjadi suatu keharusan, karena Islam telah diturunkan dari langit ke bumi dan menjadi bagian yang tidak terpisahkan dari dinamika budaya yang terus bergerak. Islam tidak saja mengatur hubungan manusia dengan Tuhannya, melainkan juga mengatur hubungan manusia dengan sesama manusia dalam kehidupan yang dinamis, serta mengatur hubungan manusia 
dengan alam lingkungannya. Dinamika pendekatan dalam studi agama (Islam), tidak lepas dari intensitas relasi agama dalam belantara hidup manusia yang sangat luas, dari kawasan teologis, sampai sosio-antropologis, bahkan kawasan politik (Mu'ammar dkk, 2012: 7).

Salah satu pendekatan yang digunakan dalam pengkajian Islam adalah pendekatan linguistik. Tulisan ini akan menguraikan tentang pendekatan linguistik dalam pengkajian Islam khususnya pengkajian sumber hukum, yang diawali dengan pengantar pemahaman tentang linguistik dan pendekatan linguistik, kemudian dilanjutkan dengan aplikasi pendekatan linguistik dalam mengkaji sumber hukum Islam.

\section{LINGUISTIK}

Menurut Ibnu Jinni, bahasa adalah bunyi yang diungkapkan oleh setiap kaum untuk menyatakan tujuannya. Ini merupakan definisi yang cermat, yang menyebutkan banyak aspek distingtif bahasa. Pertama-tama Ibnu Jinni menegaskan tabiat bunyi bahasa; mengemukakan fungsi sosial bahasa dalam ekspresi dan mengalihkan pikiran; dan mengemukakan bahwa bahasa dipakai di masyarakat. Maka setiap kaum memiliki bahasa. Para linguis modern mengemukakan berbagai definisi bahasa. Semua definisi modern ini menegaskan tabiat bunyi bahasa, fungsi sosial bahasa, dan variasi konstruksi bahasa dari satu masyarakat ke masyarakat lain (Hijazi, 2005: 1).

Menurut Kamus Bahasa Indonesia (2008: 119), bahasa adalah sistem lambang bunyi berartikulasi yang bersifat sewenang-wenang dan konvensional yang dipakai sebagai alat komunikasi untuk melahirkan perasaan dan pikiran. Menurut Kridalaksana (2001: 21), bahasa adalah sistem lambang bunyi yang arbitrer yang digunakan oleh para anggota suatu masyarakat untuk kerja sama, berinteraksi dan mengidentifikasikan diri. Menurut Brown, bahasa adalah suatu sistem komunikasi menggunakan bunyi yang diucapkan melalui organ-organ ujaran dan didengar di antara anggota-anggota masyarakat, serta menggunakan pemrosesan simbolsimbol vokal dengan makna konvensional secara arbitrer (Brown, 1987: 4).

Menurut Wibowo (2001: 3), bahasa adalah sistem simbol bunyi yang bermakna dan berartikulasi (dihasilkan oleh alat ucap) yang bersifat arbitrer dan konvensional, yang dipakai sebagai alat berkomunikasi oleh sekelompok manusia untuk melahirkan perasaan dan pikiran. Menurut Pinker (dalam Brown, 2007: 6), bahasa adalah sesuatu yang komplek, suatu keterampilan khusus, yang berkembang dalam diri anak secara spontan tanpa usaha secara sadar atau pembelajaran formal.

Berdasarkan definisi bahasa dari beberapa pakar di atas, akan 
didapatkan beberapa ciri atau sifat yang hakiki dari bahasa. Sifat atau ciri itu antara lain bahasa sebagai sistem, bahasa sebagai lambang, bahasa adalah bunyi, bahasa itu bermakna, bahasa itu arbiter, bahasa itu konvensional, bahasa itu produktif, bahasa itu unik, bahasa itu universal, bahasa itu dinamis bahasa itu bervariasi, dan bahasa itu manusiawi (Chaer, 2003: 33-59).

Dalam literatur linguistik, kita juga mengenal berbagai fungsi bahasa dengan istilah yang kadang berbeda, seperti fungsi kognitif, emotif, imperatif, seremonial, dan metalingual. Namun intinya sama bahwa bahasa mendokumentasikan peradaban (Alwasilah, 2009: 24-25). Artinya peradaban manusia dapat ditelusuri melalui teks-teks yang ditulis dalam bahasa pemilik peradaban tersebut, termasuk peradaban umat Islam yang dapat ditelusuri melalui teks-teks keagamaannya yang akan diuraikan lebih lanjut dalam tulisan ini.

\section{PENDEKATAN LINGUISTIK}

Pendekatan di sini diartikan sebagai sudut pandang (starting view), bagaimana suatu permasalahan didekati, dibahas, dan dianalisa, berdasarkan sudut (ilmu atau teori) tertentu, sehingga mendapatkan kesimpulan yang tepat. Pendekatan bersifat lebih operasional daripada paradigma, tetapi tidak seoperasional metode apalagi teknik (Nurhakim, 2004: 15).

Dalam konteks studi Islam, pendekatan dimaksud adalah cara seorang pengkaji memandang, membahas, dan menganalisa suatu objek agama Islam dengan menggunakan ilmu-ilmu atau teoriteori tertentu. Agama yang dijadikan objek studi tersebut dapat berupa dimensi ajarannya maupun realitasnya. Ilmu-ilmu atau teoriteori tertentu itu pada dasarnya dipergunakan sebagai alat bantu atau pisau analisis atas permasalahan sehingga tampak jelas objek dan lingkup studinya (Nurhakim, 2004: 15).

Dengan demikian, pendekatan yang dapat dipergunakan dalam studi Islam tidaklah satu, tetapi banyak dan beragam (Nurhakim, 2004: 15). Salah satunya adalah pendekatan linguistik yang menjadikan bahasa sebagai sudut pandang dalam memahami dimensi ajaran Islam dan realitas dari ajaran tersebut.

Filsafat abad ke-20 ditandai dengan banyaknya aliran dalam filsafat yang menaruh perhatian khusus pada permasalahan bahasa, salah satunya filsafat analitis yang berkembang di Inggris. Di sana khususnya, muncul filsuf-filsuf yang mempertanyakan dan menguraikan arti bahasa dan penggunaan bahasa yang tepat dengan menggunakan pisau analitis. Mereka tidak mempelajari bahasa sebagai tujuan akhir melainkan sebagai objek sementara agar dapat diperoleh kejelasan tentang hakikat pengetahuan konseptuaal. Aliran ini dikenal dengan sebutan filsafat analitik (Andriani, 2009: 14).

Menurut Imam Barnadib (dalam Toto Suharto, 2006: 56-57), 
pendekatan linguistik yang digunakan dalam pengkajian Islam biasanya menekankan pada dua kategori, yaitu analisis bahasa dan analisis konsep. Analisis bahasa adalah usaha untuk mengadakan interpretasi yang menyangkut pendapat atau banyak pendapat mengenai makna yang dimilikinya. Analisis bahasa dalam pendekatan bahasa akan memfokuskan pada sumber-sumber tertulis sebagai sumber pengambilan data. Tulisantulisan yang telah didokumentasi itu dianalisis bahasanya sehingga diketahui makna penggunaan bahasa tersebut.

Adapun analisis konsep digunakan untuk menganalisis istilah-istilah atau kata-kata yang mewakili gagasan atau konsep. Di sini, definisi adalah sesuatu yang diperlukan dalam menganalisis sebuah konsep. Ada dua bentuk definisi yang dikemukakan dalam analisis konsep, yaitu definisi deskriptif berdasarkan kamus, dan definisi stimulatif yang merupakan standar. Dalam melakukan analisis konsep, empat hal yang perlu diperhatikan adalah: (1) berusaha menemukan kembali arti suatu istilah, (2) meninjau suatu konsep secara objektif, (3) analisis konsep yang digunakan berdasarkan penerapan logika, dan (4) proses penemuan dalam analisis konsep merupakan pemahaman yang jelas mengenai hubungan antara pikiran, bahasa, dan realitas. Pada intinya, analisis konsep bermaksud menganalisis kata-kata yang dapat dikatakan sebagai kata kunci dari sebuah konsep, yang berbeda dengan analisis bahasa yang bermaksud mengetahui arti sebenarnya dari sesuatu hal. Kedua analisis ini sangat diperlukan dalam pendekatan kebahasaan (linguistik).

Terdapat beberapa ilmu yang terkait dengan pendekatan linguistik dalam pengkajian Islam, yaitu:

1. Ilmu Mantiq

Istilah ilmu mantiq diambil dari kata النطق yang berarti bicara atau berkata. Namun yang dimaksud dengan ilmu mantiq adalah ilmu berpikir atau logika. Hal ini karena penganut ilmu mantiq dari kalangan Muslim tertarik pada perkataan di mana antara aktifitas berpikir dan perkataan terdapat hubungan yang sangat erat sebagaimana hubungan lafaz dengan makna yang tidak bisa dipisahkan karena lafaz merupakan tanda-tanda atau alat-alat makna.

Menurut ahli mantiq, suatu ungkapan yang berupa proposisi (al-qadiyah) atau kalimat yang dituturkan seseorang dikatakan benar dan mengandung makna jika ungkapan tersebut memenuhi syarat logika formal dan material.

Dengan demikian, menurut ahli mantiq suatu ungkapan (bahasa) dikatakan benar dan bermakna kalau ungkapan tersebut mengandung bahasa logika (mantiqiyyah). Ungkapan tersebut bisa berupa pernyataan (afirmasi, al-mujibah), definisi (alta'rif), silogisme (al-qiyas), 
argumentasi (al-hujjah), dan sebagainya.

2. Semiotik Islam

Semiotik merupakan ilmu tanda. Dalam Islam, dasar-dasar semiotik ada pada konsep dilalah yaitu sesuatu yang dapat membangkitkan adanya petunjuk. Apa yang diacu atau yang ditunjukkan disebut madlul.

Menurut filsuf Islam, terdapat dua dilalah, yaitu dilalah lafziyyah (petunjuk berupa lafal, ungkapan, atau suara) dan dilalah ghair-lafziyyah (petunjuk yang bukan berupa lafal atau suara, tetapi merupakan isyarat, tanda atau simbol, jejak, fenomana alam, dan yang lainnya.

3. Hermeneutik Islam

Istilah hermeneutik berasal dari bahasa Yunani hermeneuin artinya menafsirkan. Kata bendanya adalah hermeneia yang berarti penafsiran atau interpretasi.

Terdapat dua istilah yang menunjukkan adanya kegiatan hermeneutika dalam Islam, yaitu istilah tafsir dan $t a^{\prime} w i l$. Sebagai kegiatan hermeneutika, kedua istilah ini mengandung pengertian yang sedikit berbeda. Jika tafsir berupaya mencari makna zahir dari suatu teks (ayat alquran) yang pengertiannnya secara tegas menyatakan maksud yang dikehendaki Allah SWT, sedangkan ta'wil menguatkan sebagian makna dari beberapa makna yang tercakup dalam pengertian teks (ayat) yang mungkin mempunyai beberapa pengertian.

Dengan menggunakan metode tafsir dan ta'wil ini, selanjutnya para filsuf dan ilmuwan Muslim membagi konsep makna menjadi dua jenis, yaitu manthuq dan mafhum. Kata manthuq secara bahasa berarti sesuatu yang diucapkan, dan secara istilah adalah suatu makna yang diperoleh dari suatu lafal atau susunan lafal itu sendiri. Sedangkan kata mafhum secara bahasa berarti sesuatu yang dipahami, dan secara istilah adalah suatu makna yang tidak diperoleh dari suatu lafal atau susunan lafal tetapi diperoleh dari pemahaman terhadap ucapan lafal tersebut. Kedua istilah ini lazim digunakan oleh para ahli figh dan ahli tafsir.

Apa yang telah dikembangkan para filsuf dan ilmuwan Muslim mengenai metode hermeneutik tafsir dan ta'wil ternyata telah memberikan gambaran bahwa hermeneutik dalam Islam tidak hanya dianggap sebagai seni memahami, tetapi sekaligus sebagai seni berpikir. Karenanya metode hermeneutik yang dikembangkan kaum Muslim tersebut bersifat filosofis.

Cara kerja hermeneutik telah lama dipraktikkan oleh para fisuf Muslim, teolog, ushuliy, dan mufassir dengan menggunakan metode tafsir dan ta'wil dalam memahami teks alquran dan hadis. Dengan demikian, 
hermeneutik bagi kaum Muslim bukanlah hal yang baru, melainkan sudah berabad-abad yang lalu (Hidayat, 2009: 249-259).

\section{PENDEKATAN LINGUISTIK DALAM PENGKAJIAN SUMBER HUKUM ISLAM (ALQURAN)}

Menurut Atho Mudzhar (2011: 13-14), terdapat lima bentuk gejala agama yang perlu diperhatikan ketika hendak mempelajari suatu agama. Pertama, scripture atau naskah-naskah atau sumber ajaran dan simbol-simbol agama. Kedua, para penganut atau pemimpin atau pemuka agama, yaitu yang berkenaan dengan perilaku dan penghayatan para penganutnya. Ketiga, ritus-ritus, lembaga-lembaga dan ibadat-ibadat, seperti shalat, haji, puasa, perkawinan dan waris. Keempat, alat-alat, seperti masjid, peci, dan sebagainya. Kelima, organisasi-organisasi keagamaan tempat penganut agama berkumpul dan berperan.

Serupa dengan pandangan di atas, Davamoni (1995: 21) mengemukakan bahwa objek penelitian agama adalah fakta agama dan pengungkapan. Fakta agama dan pengungkapannya dapat berupa kitab suci, pemikiran, dan kesejarahan suatu agama, simbolsimbol, budaya, perilaku, pola keberagamaan, pranata sosial, dan struktur sosial (organisasi agama) dan sebagainya.

Tulisan ini akan menguraikan pendekatan linguistik terhadap gejala atau objek pengkajian Islam tersebut, khususnya objek berupa scripture (naskah atau teks) sumber hukum Islam. Pendekatan linguistik di sini menggunakan bahasa sebagai starting view untuk mendekati, membahas, dan menganalisa naskah atau sumber hukum tersebut, sehingga ditemukan pemahaman yang benar terhadap fenomenafenomena yang muncul. Dalam hal ini, alquran sebagai naskah keagamaan yang menjadi sumber hukum utama dalam Islam dapat dikaji dan dinalisis melalui pendekatan linguistik tersebut sehingga menghasilkan pemahaman yang benar dan tepat sesuai dengan konteks.

Hasan Hanafi (As'ad, 2013) mengemukakan bahwa metode linguistik dapat mengukuhkan signifikansi linguistik sebagai pengantar untuk memahami wahyu karena wahyu bukanlah sejarah sakral, realitas unik, pribadi atau peristiwa tetapi adalah kalam yang tertulis, dibaca, didengar, dan tersusun dari bahasa manusia tertentu yaitu bahasa Arab. Sebab wahyu adalah kalam yang mengandung makna yang dikandung oleh kata-kata. Di sinilah tampak signifikansi kalam dan katakata di dalam linguistik.

Menurut Ahmad Ali Riyadi, analisis bahasa merupakan salah satu pendekatan utama dalam melakukan analisis wacana kritis (kritik wacana) sebagai instrumen dalam melakukan "kritik isi" terhadap muatan-muatan yang 
terdapat dalam teks (Riyadi, 2010: 8). Linguistik dalam hal ini memegang peran yang penting dalam memahami teks-teks keagamaan seperti alquran.

Alquran sebagai kitab yang di amanatkan kepada Muhammad dengan bahasa lisan, kemudian disampaikan kepada umatnya dengan bahasa tulisan. Dengan proses perjalanan sejarah yang panjang, alquran tetap eksis sebagai bahan kajian oleh manusia sehingga alquran digunakan dengan beranekaragam pendekatan penafsiran untuk kepentingan konteks sosial yang melingkupinya. Salah satunya adalah alquran dikaji dari sudut pandang kebahasaan yang sangat populer baik dari kalangan pemikir Islam klasik maupun pemikir Islam kontemporer (As'ad, 2013: t.h.)

Menurut Atho Mudzhar (2011: 14), dalam penelitian naskah atau sumber-sumber ajaran agama termasuk alquran, yang pertama diteliti adalah persoalan filologi, dan yang kedua adalah isi dari naskah yang ada. Sejalan dengan gagasan ini, Imam Barnadib (dalam Toto Suharto, 2006: 56-57) juga mengemukakan bahwa pendekatan linguistik yang digunakan dalam pengkajian Islam biasanya menekankan pada dua kategori, yaitu analisis bahasa dan analisis konsep.

\section{Bahasa dan Sastra Alquran}

Sebagai fakta bahasa, alquran adalah kalam Tuhan yang ditujukan kepada manusia menggunakan bahasa mereka, yakni bahasa Arab sebagai bahasa induk yang digunakan oleh masyarakat Arab untuk berkomunikasi. Kreatifitas seni kebahasaan telah mengakar di tengah masyarakat Arab jauh sebelum Islam datang. Seni-seni seperti ini telah menunjukkan eksistensinya, hingga alquran pun oleh Allah diturunkan dengan menggunakan aspek bahasa sebagai daya pemikatnya (Fatawi, 2009: 82-83).

Menurut M. Quraish Shihab (1994: 29), aspek aspek keindahan alquran dan ketelitian redaksiredaksinya ini merupakan aspek pertama dari beberapa aspek dalam alquran yang menjadi bukti kebenaran Nabi Muhammad Saw. dan kebenaran petunjuk yang disampaikannya.

Dialektika alquran dengan basis kultur bahasa di antaranya dapat dilihat dari hubungannya dengan puisi dan sajak. Puisi adalah salah satu pintu penting untuk memahami makna yang terkandung dalam alquran. Hubungan alquran dengan sajak juga menemukan basis kultur bahasanya di tengah masyarakat Arab. Munculnya sajak dalam alquran berupa fashilahfashilah antar ayat tidak lepas dari basis kultur bahasa yang mana sajak marak digunakan pada waktu itu (Fatawi, 2009: 90-96).

Sehubungan dengan hal ini, M. Quraish Shihab (1994: 62) menjelaskan bahwa salah satu mukjizat alquran adalah susunan redaksinya yang mencapai puncak tertinggi dari sastra bahasa Arab. 
Bahkan, Nur Kholis Setiawan menulis buku dengan judul "Alquran sebagai Kitab Sastra Terbesar". Menurut Setiawan (2005: 8-14), pendekatan susastra alquran dimotori oleh Amin al-Khuli di paruh akhir abad ke-20. Keseriusan al-Khuli dalam mengkaji alquran tidak bisa dilepaskan dari kajiankajiannya terhadap bahasa dan sastra Arab. Mengingat studi alquran disejajarkan dengan studi karya sastra, al-Khuli mengedepankan dua prinsip metodologis, yakni dirasah ma hawl al-qur'an dan dirasah fi al-qur'an nafsih. Kajian pertama diarahkan pada investigasi latar belakang alquran dan juga difokuskan pada aspek sosio-historisnya. Kemudian dilanjutkan pada studi tentang tentang teks alquran yang diawali dengan investigasi terhadap mufradat alquran, kemudian diikuti dengan perhatian sepenuhnya terhadap murakkabah yang tentunya didasarkan pada pengetahuan tentang qawa'id dan balaghah, tetapi penggunaannya tidak melewati batas-batas kebutuhan, yakni hanya untuk mengungkapkan keindahan sastra teks.

Aspek bacaan alquran (qira'ah) juga termasuk disiplin pokok dalam studi kitab suci alquran. Qira'ah mengandung makna oral. Sebagai istilah teknis, qira'ah tidak hanya digunakan untuk merujuk pada tindakan atau praktek membaca keras alquran tetapi juga pada bacaan "khusus" (yakni pengucapan, pelafalan) suatu kata, frase, atau ayat dalam alquran (Graham, 2002: 37-38).

Qira'at sebagai ilmu resmi mencakup studi dan transmisi berbagai bacaan (qira'at) teks Usmani dan juga seni bacaan oral atau tajwid dengan bebagai tradisi vokalnya. Sebagai suatu ilmu, ilmu qira'at wa tajwid menyajikan tradisi-tradisi Muslim dalam studi teks alquran. Studi ini tentu saja membutuhkan pengetahuan tentang ilmu-ilmu lain, dari tata bahasa (nahw) filologi (lughah), hingga retorika (balaghah), ortografi (rasm), dan khususnya tafsir. Fokusnya adalah pada pemeliharaan dan penciptaan ulang firman Tuhan yang hidup secara terus-menerus sebagaimana Ia diturunkan dalam bentuk oral kepada Muhammad (Graham, 2002: 38).

Kehadiran tilawah alquran dengan ritme yang indah juga dapat dijumpai dalam masyarakat Muslim tradisional dan modern (Graham, 2002: 45). Berbagai jenis lagu bacaan diciptakan sehingga bacaan alquran terdengar indah dengan tetap menjaga kebenaran dan ketepatan qiraat dan tajwid.

Namun supremasi fungsi bahasa lisan alquran tidak menggiring kita untuk mengabaikan pengaruh bentuk tulisan alquran yang cukup kuat. Bentuk tulisan alquran tersebut telah mengembangkan dua macam seni gambar, yakni kaligrafi dan dekorasi buku. Seni kaligrafi dihubungkan dengan alquran adalah untuk mentransformasikan teks tertulis ke 
dalam bentuk tulisan. Sedangkan dekorasi buku merupakan seni yang dikembangkan melalui berbagai usaha, seperti menciptakan beberapa tanda untuk mendefinisikan bentukbentuk tulisan bahasa Arab yang mirip dengannya, meletakkan beberapa tanda untuk menunjuk beberapa huruf hidup di dalam maupun di akhir kata, dan memberi nomor ayat setiap surat serta menunjuk permulaan dan akhir setiap surat (Zayd, 2003: 100-101).

\section{Konsep-konsep Istilah dalam Alquran}

Pemahaman tentang konsepkonsep keagamaan yang diawali dari pemahaman dari aspek kebahasaan sangat diperlukan. Abu Zaid seperti dikutip oleh Fatawi (2009: 98) mencontohkan kata shalah yang semula memiliki arti "do'a" ditransformasi oleh alquran menjadi sebuah konsep ibadah ritual; kata zakah yang sebelumnya berarti "pertumbuhan" dirubah menjadi sebuah konsep penyucian diri lewat harta benda; dan kata shaum yang semula bermakna "pencegahan diri" dijadikan sebagai konsep penyucian jiwa dalam wujud menghindari makan dan minum dalam waktu sehari.

Demikian juga dengan konsep Tuhan yang digambarkan dalam gaya linguistik yang luar biasa oleh alquran menggambarkan

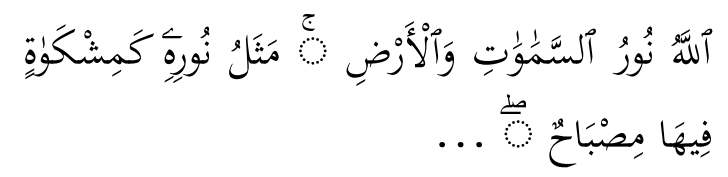

Tuhan adalah cahaya langit dan bumi; perumpamaan cahaya Tuhan seperti sebuah relung yang di dalamnya terdapat pelita... (Q.S. anNur [24]: 35)

Pemahaman literal yang jelas dari sifat puitis strukur linguistik ayat ini menggiring kepada penegakan doktrin seluruh alam sebagai cahaya emanasi dari emanasi Tuhan (Zayd, 2003: 115-117).

\section{Hermeneutika Alquran}

Di antara ciri alquran adalah diturunkan secara kontekstual atau menurut kebutuhan masyarakat. Ia memberikan petunjuk penyelesaian masalah, dan mengajak dialog dalam konteks budaya yang berkembang saat ini. Jika alquran memberikan petunjuk hidup yang universal, maka tidak cukup hanya dipelajari dari sisi teks-teksnya, atau dari segi teks dan konteks turunnya saja, tetapi juga harus memperhatikan konteks alquran dipahami dan ditafsiri seperti sekarang. Bahkan diperlukan konteks sejarah sebagai bahan analisa perbandingan perkembangan alquran serta penafsirannya dari masa ke masa. Hal ini dilakukan untuk menangkap inti ajaran setelah mengetahui 'illat hukumnya (Nurhakim, 2004: 51-52). Di samping itu, menurut Zayd, meskipun terwujud dalam sistem linguistik bahasa Arab, tetapi teks alquran memiliki kekhasannya tersendiri. Sebagai sebuah teks yang unik, alquran menggunakan beberapa sandi linguistik tertentu yang dinamis dalam upaya untuk 
menyampaikan pesan khasnya (Zayd, 2003: 95).

Salah satu metode yang ditawarkan di sini adalah menafsirkan teks-teks tersebut dalam perspektif historis dan sekaligus konteks sosialnya. Penafsiran semacam ini sekarang dikenal dengan istilah metode hermeneutika (Nurhakim, 2004: 53). Menurut Palmer (dalam Suharyanta, 2011: 163), secara etimologi hermeneutika berasal dari bahasa Yunani hermenuein yang berarti "menafsirkan" dan hermeniea yang berarti "tafsiran". Lebih lanjut, Suharyanta menjelaskan bahwa secara terminologis, hermeneutika adalah proses mengubah sesuatu dari situasi dan makna yang tidak diketahui menjadi dimengerti, namun untuk mengerti tidaklah mudah, banyak hal yang mempengaruhinya, salah satunya adalah bahasa. Untuk mengerti dan membuat interpretasi harus memakai bahasa. Sehingga dapat dikatakan bahwa hermeneutika adalah cara baru untuk bergaul dengan bahasa.

\section{Adapun}

kerangka

metodologinya terdiri dari tiga hal. Pertama, memahami teks (nash) serta konteks sejarahnya. Kedua, menangkap pesan dasar teks (ruh nash). Dan ketiga, mengkaji konteks kekinian serta mendialogkannya dengan pesan dasar teks (Nurhakim, 2004: 53). Adapun beberapa hal yang membedakan hermeneutika modern adalah menggunakan pendekatan semantik, pendekatan semiotik, dan pendekatan filologi dalam kajiannya. Hermeneutika modern befungsi menjelaskan ide dalam pikiran melalui kata-kata, menjelaskan makna yang masih samar menjadi lebih jelas, menerjemahkan suatu bahasa ke dalam bahasa lain yang lebih dikuasai, dan mencari makna yang relevan dan kontekstual di era sekarang (Suharyanta, 2011: 165166).

\section{PENUTUP}

Pendekatan dalam pengkajian Islam harus sesuai dengan objek yang dikaji. Pendekatan linguistik sebagai salah satu pendekatan yang dapat digunakan dalam pengkajian sumber hukum Islam mempunyai objek kajian berupa scripture (naskah atau teks). Oleh karena itu, alquran sebagai naskah keagamaan dapat dikaji dan dinalisis melalui pendekatan linguistik ini sehingga menghasilkan pemahaman yang benar dan tepat.

\section{DAFTAR KEPUSTAKAAN}

Abdullah, Amin. 1996. Studi Agama Normativitas atau Historisitas. Yogyakarta: Pustaka Pelajar.

Alwasilah, A. Chaidar. 2009. Filsafat Bahasa dan Pendidikan. Bandung: PT Remaja Rosdakarya.

Andriani, Dewi. 2009. Ambigutias Constantive dan Performative. Skripsi program sarjana, tidak 
diterbitkan, Universitas Indonesia

As'ad, Tauhedi. 2013. Diskursus Linguistik Modern: Suatu Pendekatan Dalam Melacak Bahasa Tuhan. Diakses dari http:/ / tauhediasad.blogspot.co m pada 13 September 2015.

Brown, H.D. 2007. Principles of Language Learning and Teaching Fifth Edition. New York: Pearson Education.

Brown, H.G. 1987. Principles of Language Learning and Teaching. Englewood Cliffs NJ: Prentice Hall Inc.

Chaer, Abdul. 2003. Linguistik Umum. Jakarta: Rineka Cipta.

Dhavamoni, Mariasusai. 1995. Fenomenologi Agama. Yogyakarta: Kanisius.

Fatawi, Faisol. 2009. Tafsir Sosiolinguistik. Malang: UINMalang Press.

Graham, William A. 2002. Alquran sebagai Kata Terucap. Dalam Richard C. Martin (ed). 2002. Pendekatan Kajian Islam dalam Studi Agama. Terj. Zakiyuddin Bhaidawy. Surakarta: Muhammadiyah University Press.

Hidayat, Asep Ahmad.2009.Filsafat Bahasa. Bandung: PT Remaja Rosdakarya.

Hijazi, Mahmud Fahmi. 2005. Linguistik Arab.Terj. Wagino HH\& Ed. Sugiarto. Bandung: PSIBA Press.
Kridalaksana, Harimurti. 2001. Kamus Linguistik: Edisi Ketiga. Cet. ke-5. Jakarta: PT Gramedia Pustaka Utama.

Mu'ammar, Arfan dkk. 2012. Studi Islam Perspektif Insider/Outsider. Yogyakarta: Irchisod.

Mudzhar, Atho. 2011. Pendekatan Studi Islam. Yogyakarta: Pustaka Pelajar.

Nurhakim, Moh. 2004. Metodologi Studi Islam. Malang: UMM Press.

Riyadi, Ahmad Ali. 2010.Filsafat Pendidikan Islam. Yogyakarta: Teras

Setiawan, Nur Kholis. 2005. AlQur'an Kitab Sastra Terbesar. Yogyakarta: elSAQ Press.

Shihab, M. Quraish. 1994. Membumikan alquran: Fungsi dan Peran Wahyu dalam Kehidupan Masyarakat. Bandung: Mizan

Suharto, Toto. 2006. Filsafat Pendidikan Islam. Yogyakarta: Ar-Ruzz

Suharyanta. 2011. Tafsir dan Hermeneutika. Dalam Khamdan dkk. 2011. Studi AlQur'an: Teori dan Metodologi. Yogyakarta: Idea Press

Suprayogo, Imam. 2001. Metodologi Penelitian Sosial-Agama. Bandung: Rosdakarya.

Tim Penyusun Kamus Pusat Bahasa. 2008. Kamus Bahasa Indonesia. Jakarta: Pusat Bahasa.

Wibowo, Wahyu. 2001. Manajemen Bahasa. Jakarta: Gramedia. 
Zayd, Nashr Hamid Abu. 2003. AlQur'an, Hermeneutika dan Kekuasaan. Terj. Dede Iswadi dkk. Bandung: Rqis. 